\title{
Human Umbilical Cord Blood for Transplantation Therapy in Myocardial Infarction
}

\author{
Sandra A Acosta ${ }^{1 \#}$, Nick Franzese ${ }^{1 \#}$, Meaghan Staples ${ }^{1 \#}$, Nathan L Weinbren ${ }^{1 \#}$, Monica Babilonia ${ }^{1}$, Jason Patel ${ }^{1}$, Neil Merchant $^{1}$, Alejandra $^{1}$ \\ JacotteSimancas ${ }^{1}$, Adam Slakter ${ }^{1}$, Mathew Caputo ${ }^{1}$, Milan Patel ${ }^{1}$, Giorgio Franyuti ${ }^{1}$, Max H Franzblau ${ }^{1}$, Lyanne Suarez ${ }^{1}$, Chiara Gonzales-

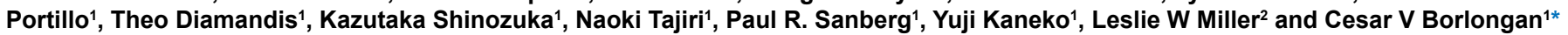 \\ ${ }^{1}$ Center of Excellence for Aging and Brain Repair, Department of Neurosurgery and Brain Repair, University of South Florida Morsani College of Medicine, Tampa, FL, \\ USA \\ ${ }^{2}$ USF Heart Institute, University of South Florida Morsani College of Medicine, Tampa, FL, USA \\ \#Equally contributed to this paper
}

\begin{abstract}
Cell-based therapy is a promising therapy for myocardial infarction. Endogenous repair of the heart muscle after myocardial infarction is a challenge because adult cardiomyocytes have a limited capacity to proliferate and replace damaged cells. Pre-clinical and clinical evidence has shown that cell based therapy may promote revascularization and replacement of damaged myocytes after myocardial infarction. Adult stem cells can be harvested from different sources including bone marrow, skeletal myoblast, and human umbilical cord blood cells. The use of these cells for the repair of myocardial infarction presents various advantages over other sources of stem cells. Among these are easy harvesting, unlimited differentiation capability, and robust angiogenic potential. In this review, we discuss the milestone findings and the most recent evidence demonstrating the therapeutic efficacy and safety of the transplantation of human umbilical cord blood cells as a stand-alone therapy or in combination with gene therapy, highlighting the importance of optimizing the timing, dose and delivery methods, and a better understanding of the mechanisms of action that will guide the clinical entry of this innovative treatment for ischemic disorders, specifically myocardial infarction.
\end{abstract}

Keywords: Myocardial infarction; Cardiomyocytes; Umbilical cord blood; Angiogenesis; Gene therapy

Abbreviations: MI: Myocardial Infarction; SC: Stem Cells; MSCs: Mesenchymal Stem Cells; EPCs: Endothelial Progenitor Cells; HUBC: Human Umbilical Cord Blood; VSELs: Very Small Embryonic-like Stem Cells; MYHC: Mmyosin Ventricular Heavy Chain Alpha/ Beta; ERK: Extracellular Signal Related Kinases; S1P: Sphigosine-1 Phosphate; CMCM: Cardiac Myocytes Conditioning Medium; MHC: Myosin Heavy Chain; VEGF-B: Vascular Endothelial Growth Factor-B; VEGF: Vascular Endothelial Growth Factor; AAV: Adeno Associated Virus; LAD: Left Anterior Descending Coronary Artery; TNF-alpha: Tumor Necrosis Factor-alpha; MCP-1: Monocyte/ macrophage Chemoattractant Protein; MIP: Monocyte Inflammatory Protein; INF-gamma: Interferon-gamma; BMSC: Marrow Mesenchymal SCs; SH: Silk Fibroin/hyaluronic Acid; IV: Intravenous; IC: Intracoronary; USSCs: Unrestricted Human Somatic Stem Cells; LV: Left Ventricular; FS: Fractional Shortening; RWMS: Regional Wall Motion Score; LVEDP: Left Ventricular End Diastolic Pressure; CMCs: Cardiomyocytes; SFD-1: Stromal Cell Derived Fator-1; LVEF: Left Ventricular Ejection Fraction; AAVs: Adeno Associated viral Vectors; 3D: Three-Dimensional; BDNF: Brain Derived Neurotrophic Factor

\section{Introduction}

Myocardial infarction (MI) remains one of the leading causes of death. The resulting heart failure from MI is preceded by a pathological cascade of events including the irreversible loss of myocytes, scarring of the myocardial tissue, expansion of the infarct area, concentric hypertrophy, and left ventricular dilation $[1,2]$.

The repair of damaged cardiac tissue or vascular tissue may be achieved along with improved myocardial function $[3,4]$. However, there is still a gap in clinical therapies for MI. While there are native cardiac cells in the heart, their population levels remain too small to make a therapeutic difference [5-7]. Transplantation for MI was first suggested in 1994 [8]. Although recent studies have indicated that injection of bone marrow mononuclear cells aids in cardiac remodeling and guard against fibrosis [9], additional optimization laboratory studies are warranted prior to initiating large-scale clinical trials of transplantation therapy for MI. The use of adult stem cell (SC) for transplantation therapy has been demonstrated to afford benefits in MI [10]. Accumulating preclinical evidence of safety and efficacy of SC therapy for MI, and the entry of SC therapy to the clinic, provided the impetus for us to update a review of the field [11].

Various types of cells have been discussed and tested as a potential therapy for the repair of damaged myocardium. Hematopoetic progenitor cells have been shown to reduce apoptosis $[12,13]$. Human amniotic epithelial cells have been demonstrated to differentiate in cardiomyocyte-like cells following transplantation [14]. Mesenchymal stem cells (MSCs) [15-19], skeletal muscle cells [20], skeletal myoblasts [21-24], endothelial precursor cells [25] cardiac progenitor cells [26], and resident cardiac stem cells [27] have been documented to enhance cardiac function and endothelial progenitor cells (EPCs) are being studied for the same result [28]. However, there is disagreement over the optimal cell graft for clinical application. Cultured MSCs from aging bone marrow display a lack of self-renewal, proliferation,

*Corresponding author: Cesar V. Borlongan PhD, Professor and Vice-Chairman for Research, Department of Neurosurgery and Brain Repair, University of South Florida, 12901 Bruce B. Downs Blvd., Tampa 33612, FL, USA, Tel: +1 813974 3154; Fax: +1 813974 3078; E-mail: cborlong@health.usf.edu

Received June 04, 2013; Accepted June 28, 2013; Published July 01, 2013

Citation: Acosta SA, Franzese N, Staples M, Weinbren NL, Babilonia M, et al. (2013) Human Umbilical Cord Blood for Transplantation Therapy in Myocardia Infarction. J Stem Cell Res Ther S4: 005. doi:10.4172/2157-7633.S4-005

Copyright: (c) 2013 Acosta SA, et al. This is an open-access article distributed under the terms of the Creative Commons Attribution License, which permits unrestricted use, distribution, and reproduction in any medium, provided the original author and source are credited. 
adhesion, and integration into vascular tissue when transplanted to a damaged heart [29-31].

Autologous transplantation is currently a topic of much interest, as this therapy circumvents graft-host immune disease. However, this method is not advantageous in aging and chronically ill populations, who are functional SCs are reduced, limiting any recovery or reparative ability of damaged tissue [29-31].

The limitations of various cells, including bone marrow derived MSCs, prompts exploration of more suitable SC donor sources for transplantation in MI. Human umbilical cord blood (HUCB) cells may overcome these limitations with favorable reparative outcomes, particularly in the aged population where autologous cells are not as beneficial [32-36]. Their supply is much larger than that of the autologous cells, as HUCB cells are present in the blood of umbilical cord, which are in ample supply and can be easily harvested; they can also self-renew, proliferate, and differentiate into varying lineages. Furthermore, HUCB remain viable even after long periods of cryopreservation $[13,15,16,21,25]$. The risk of losing protein signaling and damaging other protein is minimal in HUCB cells $[4,13,15,16,21,25,27-37]$.

The survival of transplanted HUCB and their differentiation into myocytes or endothelial cells appear necessary, at least acutely, to promote left ventricular remodeling [38-53]. However, the extent and stability of efficacy of HUCB cells for repair of MI require more preclinical investigations, along with the need to elucidate the mechanism through which the cells contribute to myocardial repair $[3,54]$. Table 1 reviews the literature by dosage and delivery route. Optimizing the HUCB cells transplantation regimen for the amelioration and repair of the failing heart post-MI is a key translational research goal for this evolving area of research. Additionally, this update serves as an evaluation of the mechanisms of action mediating the therapeutic benefits of HUCB cells in MI may reveal insights on the reparative capacity of the cells.

\section{Benefits of Utilizing HUCB}

HUCB cells have several properties that make them advantageous for cell transplantation therapies over other sources. Unlike bone marrow and embryonic derived SCs, harvesting HUCB cells is noninvasive and does not put the mother or the infant at risk $[55,56]$. These cells can be cultured to an unlimited supply, avoiding numerous ethical issues that plague other SCs $[57,58]$. To harvest the HUCB cells, a physician clamps the umbilical cord and punctures the umbilical vein with a syringe to draw out blood into a bag with anticoagulants and nutrients. The blood is cleaned of infectious agents prior to cryopreservation and finally stored in a blood bank for future use [59]. Once harvested, HUCB cells can easily proliferate, and be indefinitely cultured $[57,58,60]$.

Cryopreservation does not hinder any proliferation potential, making HUCB cells viable and long lasting [59]. Furthermore, cryopreservation raises the amount of retroviral receptor mRNA in cord blood increasing its ability to transduce retroviral vectors. This enhanced amphotrophic retroviral receptor expression facilitates the utility of, gene therapy as these receptors are a central target for transduction of genes of interest [61].

HUCB is also a richer source of hematopoietic stem and progenitor cells with higher proliferation and expansion potential than bone marrow [62-65]. There is approximately $4 \%$ higher frequency of CD34+, CD38-, and CD133+ cells in primitive hematopoietic SCs derived from HUCB than in bone marrow $[32,66,67]$. These findings suggest the higher benefits transplantation of HUCB could yield of bone marrow.

One of the biggest challenges in cell based treatment and transplantation is to overcome graft rejection. HUCB cells have the benefit of having immature immunogenicity, suggesting that these cells will have a lower incidence of graft-versus-host disease as compared to other varieties of SC $[31,56,62,68-71]$. Recently, researchers discovered that HUCB contains a small percentage of very small embryonic-like SCs (VSELs) another source of pluripotent SCs [72-74]. Additionally, it has been shown that HUCB cells possess the ability to repair muscle cells and endothelial cells due to their myogenic and angiogenic properties, indicating that they would be well suited for repairing damaged myocardium [33-41,43-45,49,55,57]. HUCB cells have a long track record of safety profile in successful clinical transplantation $[58,59,75]$. Altogether, these advantages support the notion that adult SCs provide a high level of safety and efficacy to the transplant recipient.

\section{HUCB Mechanisms of Cardiac Repair}

There is still much uncertainty for the exact mechanism by which HUCB cells ameliorate cardiac deficits or how they reduce infarct volume. The various populations of SCs found in the HUCB highlight multi-pronged mechanisms. Immunophenotyping and analysis of the function properties reveal a close resemblance to bone marrow-derived SC characteristics $[76,77]$, that led to much speculation that HUCB cells resemble bone marrow SCs. However, the exact mechanisms of action underlying the beneficial effects of the HUCB cells are unknown; below are a few of the more common postulated therapeutic pathways.

\section{Cellular Cardiomyoplasty}

Cellular cardiomyoplasty may result in improvement and reversion of the adverse hemodynamic and neurohormonal imbalance post MI. HUCB is a rich source for HSCs and MSCs, which specifically are known to differentiate into other cell types such as cardiomyocytes, osteocytes, chondrocytes, and fat cells $[4,32,60,78]$. That SCs from HUCB can differentiate into cardiomyocytes suggests that cellular cardiomyoplasty is likely involved in the repair damaged myocardium and increase contractile performance after SC transplantation $[13,40,41,45,69,76,77,79-84]$.

HUCB-derived MSCs have been shown to regenerate into cardiomyocytes in vitro. Using a medium of low serum DMEM to form an adherent layer, the expanded HUCB cells were added to a supplemented medium with 5-azacytidineto induce cardiomyocytes. To identify cells similar to cardiomyocytes, cardiogenic specific contractile protein troponin $\mathrm{T}$ staining was performed, revealing $70 \%$ of the cells had differentiated into cardiomyocyte-like cells [85]. A similar study analyzed the role of HUCB CD133+ cells by culturing them either in medium supporting endothelium-differentiation or cardiomyocyte-differentiation endothelium markers such as VEcadherin, CD146, KDR, and CD105, as well as morphofunctional features of endothelium in endothelial-supporting cultures of cardiac muscle proteins such as troponin I and myosin ventricular heavy chain alpha/beta; MYHC were discovered in the endotheliumoriented cultures. In the cardiomyocyte-oriented cultures, specific gene expression of GATA 4, NKX2.5, troponin I, and MYHC were found. Thus, HUCB CD133+ cells have been implicated to promote myogenesis and angiogenesis [86].

Cardiomyocyte differentiation of HUCB has been induced in vitro [85-89]. One novel approach for directing cardiomyocyte differentiation examined the creation of a culture medium containing 
Citation: Acosta SA, Franzese N, Staples M, Weinbren NL, Babilonia M, et al. (2013) Human Umbilical Cord Blood for Transplantation Therapy in Myocardial Infarction. J Stem Cell Res Ther S4: 005. doi:10.4172/2157-7633.S4-005

Page 3 of 11

\begin{tabular}{|c|c|c|c|c|c|c|c|}
\hline $\begin{array}{l}\text { HUCB Dose } \\
\text { and Delivery } \\
\text { Route }\end{array}$ & $\begin{array}{l}\text { Time of Delivery } \\
\text { Post AMI }\end{array}$ & Cell Type & MI Model & Lesion Size & Potential Mechanism of Action & Recovery & Source \\
\hline $1 \times 10^{8} \mathrm{IC}$ & 1 Week & $\begin{array}{l}\text { USSC from } \\
\text { HUCB }\end{array}$ & $\begin{array}{l}\text { Swine with } \\
\text { balloon occlusion }\end{array}$ & Increased & $\begin{array}{l}\text { USSC survived in the infarct border } \\
\text { zone at } 5 \text { weeks, did not express } \\
\text { cardiomyocyte/endothelial markers. } \\
\text { Micro infarctions were found in } \\
\text { heart }\end{array}$ & $\begin{array}{l}\text { No difference in global and } \\
\text { regional LV function at } 5 \text { weeks }\end{array}$ & {$[98]$} \\
\hline $\begin{array}{l}1.1 \mathrm{X} 10^{5} \mathrm{IM} \\
2.1 \mathrm{X} 106 \mathrm{IM}\end{array}$ & 20 Minutes & $\begin{array}{l}\text { USSC from } \\
\text { HUCB }\end{array}$ & $\begin{array}{l}\text { Rats with LAD } \\
\text { ligation }\end{array}$ & Decreased & $\begin{array}{l}\text { cardiomyocytes generation and } \\
\text { vascularization are dose-dependent }\end{array}$ & $\begin{array}{l}\text { LV structural integrity was } \\
\text { upheld. No statistical difference } \\
\text { between the groups in fractional } \\
\text { shortening }\end{array}$ & 111 \\
\hline $\begin{array}{l}1.2 \times 10^{5} \mathrm{IM} \\
2.2 \mathrm{X} 103 \mathrm{IM}\end{array}$ & 24 hours & $\begin{array}{l}\text { 1. Unseparated } \\
\text { CD } 34+\text { cells } 2 . \\
\text { FACS sorted } \\
\text { CD34+KDR+ or } \\
\text { CD34-KDR- }\end{array}$ & $\begin{array}{l}\text { NOD-SCID } \\
\text { mouse with LAD } \\
\text { ligation }\end{array}$ & $\begin{array}{l}\text { 1. Decreased } 2 . \\
\text { Decreased }\end{array}$ & $\begin{array}{l}\text { CMC apoptosis and fibrosis were } \\
\text { decreased and lownumber of HNA+ } \\
\text { nuclei within a CMC context was } \\
\text { found at } 21 \text { days after MI }\end{array}$ & $\begin{array}{l}\text { Improved L VE DP and dp/ } \\
\operatorname{dt}(\max ) \text { at } 3 \text { and } 4 \text { months PT }\end{array}$ & 38 \\
\hline $5 \times 10^{5} \mathrm{IM}$ & NA & $\begin{array}{l}\text { HUCB } \\
\text { mononuclear } \\
\text { cells } \\
\text { overexepressing } \\
\text { CD } 133^{+}\end{array}$ & $\begin{array}{l}\text { Mice with LAD } \\
\text { ligation }\end{array}$ & Decreased & $\begin{array}{l}\text { Cells were detected only at the } 48 \\
\text { hour marker }\end{array}$ & $\begin{array}{l}\text { Higher capillary density, showed } \\
\text { less improved myocardial } \\
\text { contractility then bone marrow } \\
\text { derived cells }\end{array}$ & 42 \\
\hline $\begin{array}{l}1.5 \mathrm{X} 10^{6} \mathrm{IM} \\
2.4 \mathrm{X} 106 \mathrm{IM}\end{array}$ & $1-2$ hours & $\begin{array}{l}\text { HUCB } \\
\text { mononuclear } \\
\text { cells }\end{array}$ & $\begin{array}{l}\text { Rats with LAD } \\
\text { ligation }\end{array}$ & $\begin{array}{l}\text { 1. Decreased } 2 . \\
\text { Decreased }\end{array}$ & NA & $\begin{array}{l}\text { IM had more improved cardiac } \\
\text { function than IV, } 4 \times 10^{6} \text { had } \\
\text { a greater decrease in infarct } \\
\text { volume }\end{array}$ & 109 \\
\hline $1 \mathrm{X} 10^{6} \mathrm{IM}$ & 1 hours & $\begin{array}{l}\text { HUCB } \\
\text { mononuclear } \\
\text { progenitor cells }\end{array}$ & $\begin{array}{l}\text { Rats with LAD } \\
\text { ligation }\end{array}$ & Decreased & NA & $\begin{array}{l}\text { Improved E F, dp /dt(max), and } \\
\text { anteroseptal wall tickening at } 3 \\
\text { and } 4 \text { months P T }\end{array}$ & 40 \\
\hline $1 \times 10^{6} \mathrm{IM}$ & 30 minutes & $\begin{array}{l}\text { HUCB EP C } \\
\text { expressing CD } \\
34^{+}\end{array}$ & $\begin{array}{l}\text { Rats with } \\
\text { transient LAD } \\
\text { ligation }\end{array}$ & NA & $\begin{array}{l}\text { Positive human staining for new } \\
\text { vascular structures }\end{array}$ & $\begin{array}{l}\text { Vascular structures formed ; left } \\
\text { ventricular ejection fraction }\end{array}$ & 45 \\
\hline $1 \times 10^{6} \mathrm{IM}$ & Immediately & $\begin{array}{l}\text { HUCB } \\
\text { mononuclear } \\
\text { cells expressing } \\
\text { CD } 34^{+} \text {cocultured } \\
\text { with adeno } \\
\text { associate virus }\end{array}$ & $\begin{array}{l}\text { Micewith LAD } \\
\text { ligation }\end{array}$ & Decreased & $\begin{array}{l}\text { Cells were integrated into } \\
\text { cardiomycytes. Increased capillary } \\
\text { density }\end{array}$ & $\begin{array}{l}\text { Smaller } L V \text { activity and higher } \\
\text { ejection fraction as well as } \\
\text { improved fractional shortening }\end{array}$ & 47 \\
\hline $\begin{array}{l}1.1 \times 10^{6} I M \\
2.1 \times 10^{6} I M\end{array}$ & $\begin{array}{l}1.2 \text { hours } 2.24 \\
\text { hours }\end{array}$ & $\begin{array}{l}\text { HUCB } \\
\text { mononuclear } \\
\text { cells }\end{array}$ & $\begin{array}{l}\text { Rats with LAD } \\
\text { ligation }\end{array}$ & $\begin{array}{l}\text { 1. Decreased } 2 . \\
\text { Decreased }\end{array}$ & $\begin{array}{l}\text { Limited expression of TNF-alpha, } \\
\text { MCP-1, MIP, and INF -gamma in } \\
\text { acutely infarcted myocardium }\end{array}$ & NA & 51 \\
\hline $1.5 \times 10^{6} \mathrm{IM}$ & Immediately & $\begin{array}{l}\text { HUCB } \\
\text { MSC s } \\
\text { expressing } \\
\text { GATA-4 }\end{array}$ & $\begin{array}{l}\text { Rats with LAD } \\
\text { ligation }\end{array}$ & Decreased & $\begin{array}{l}\text { MSC survival increased with the } \\
\text { expression of GATA-4 }\end{array}$ & $\begin{array}{l}\text { Improved L V anterior wall } \\
\text { thickness }\end{array}$ & 39 \\
\hline $5 \times 10^{6}$ & 1 hours & $\begin{array}{l}\text { HUCB } \\
\text { mononuclear } \\
\text { cells combined } \\
\text { with fixation of } \\
\text { collagen matrix }\end{array}$ & $\begin{array}{l}\text { Mice with LAD } \\
\text { ligation }\end{array}$ & NA & Increased infarcted area thickness & $\begin{array}{l}\text { Improved left ventricular } \\
\text { enddiastolic volume at day } 45 \\
\text { PT }\end{array}$ & 53 \\
\hline $5 \times 10^{6} \mathrm{IM}$ & 2 Weeks & $\begin{array}{l}\text { USSCs from } \\
\text { HUCB }\end{array}$ & $\begin{array}{l}\text { Rats with left } \\
\text { coronary artery } \\
\text { ligation }\end{array}$ & NA & $\begin{array}{l}\text { Transplanted cells seen, with some } \\
\text { expressing cardiac tropinin-T, von } \\
\text { Wille brand factor, and smooth } \\
\text { muscle actin. Capillary and arteriole } \\
\text { density were also markedly } \\
\text { increased }\end{array}$ & $\begin{array}{l}\text { Improved LVEF and left } \\
\text { ventricular dimension and } \\
\text { posterior wall thickness at } 2 \text { and } \\
4 \text { weeks PT }\end{array}$ & 49 \\
\hline $1 \mathrm{X} 10^{7} \mathrm{IM}$ & Immediately & $\begin{array}{l}\text { HUCB } \\
\text { mononuclear } \\
\text { cells }\end{array}$ & $\begin{array}{l}\text { Rats with LAD } \\
\text { ligation }\end{array}$ & Decreased & $\begin{array}{l}\text { Transplanted cells were detected. } \\
\text { Collagen density was decreased. } \\
\text { Expression of VEGF and number of } \\
\text { micro vessels were increased }\end{array}$ & $\begin{array}{l}\text { Improved left ventricular wall } \\
\text { motion, LVE DP and dp / dt } \\
\text { (max) at } 3 \text { and } 4 \text { weeks PT }\end{array}$ & 50 \\
\hline $100 \times 10^{6} \mathrm{IM}$ & 4 Weeks & $\begin{array}{l}\text { USSC s from } \\
\text { HUCB }\end{array}$ & $\begin{array}{l}\text { Pigs occluded } \\
\text { by coil }\end{array}$ & NA & $\begin{array}{l}\text { Grafted cells were detected at } 4 \\
\text { weeks PT }\end{array}$ & $\begin{array}{l}\text { Improved wall motion, regional } \\
\text { perfusion, and EF. Scar } \\
\text { thickness at } 4 \text { weeks PT }\end{array}$ & 46 \\
\hline $\begin{array}{l}1.0 .5 \times 10^{6} \mathrm{IV} \\
2.4 \times 10^{6} \mathrm{IV}\end{array}$ & 1-2 hours & $\begin{array}{l}\text { HUCB } \\
\text { mononuclear } \\
\text { cells }\end{array}$ & $\begin{array}{l}\text { Rats with LAD } \\
\text { ligation }\end{array}$ & $\begin{array}{l}\text { 1. Decreased } \\
\text { 2. Decreased }\end{array}$ & NA & $\begin{array}{l}\text { Less improvement than } \\
\text { IM. } 4 \times 10^{6} \text { produced better } \\
\text { improvement }\end{array}$ & 109 \\
\hline $1.2-2 \times 10^{6} \mathrm{IV}$ & 7 days & $\begin{array}{l}\text { HUCB CD 133+ } \\
\text { cells }\end{array}$ & $\begin{array}{l}\text { Rats with LAD } \\
\text { ligation }\end{array}$ & Decreased & Human cells were detected & $\begin{array}{l}\text { LVFS and anterior wall thickness } \\
\text { were improved at } 1 \text { month PT }\end{array}$ & 48 \\
\hline $2 \times 10^{5} \mathrm{IV}$ & 20 minutes & $\begin{array}{l}\text { HUCB CD 34++ } \\
\text { cells }\end{array}$ & $\begin{array}{l}\text { Rats with LAD } \\
\text { ligation }\end{array}$ & NA & $\begin{array}{l}\text { CD34+, CD45+, and PCAM- } 1+\text { cells } \\
\text { enhanced neo vascularization at } 4 \\
\text { weeks after PT }\end{array}$ & $\begin{array}{l}\text { Improved FS and } \mathrm{dP} / \mathrm{dt}(\max ) \text { at } \\
4 \text { weeks PT }\end{array}$ & 41 \\
\hline
\end{tabular}




\begin{tabular}{|l|l|l|l|l|l|}
\hline $6 \times 10^{6} \mathrm{IV}$ & 24 hours & $\begin{array}{l}\text { HUCB } \\
\text { mononuclear } \\
\text { cells }\end{array}$ & $\begin{array}{l}\text { Mice with LAD } \\
\text { ligation }\end{array}$ & Decreased & $\begin{array}{l}\text { HUCB-derived cells and human } \\
\text { endothelial cells were detected. } \\
\text { Expression of SD-1 mRNA and } \\
\text { capillary density were increased. } \\
\text { Less collagen deposition was } \\
\text { found. Differentiation not seen. }\end{array}$ \\
\hline $6 \times 10^{6} \mathrm{IV}$ & 24 hours & $\begin{array}{l}\text { HUCB } \\
\text { mononuclear } \\
\text { cells }\end{array}$ & $\begin{array}{l}\text { Mice with LAD } \\
\text { ligation }\end{array}$ & Decreased & $\begin{array}{l}\text { HUCB cells showed endothelial cell } \\
\text { markers, but no monocyte markers. }\end{array}$ \\
\hline
\end{tabular}

Table 1: Transplant Regimen and Mechanism of Action of HUCB in Myocardial Infarction.

different signaling factors in sequence. To reveal cardiomyocyte-like phenotype in HUCB CD133+ cells, the authors demonstrated the expression of intracellular cardiac specific makers such as cardiacspecific $\alpha$-actin, myosin heavy chain, and troponin I. Additional tests revealed that the phenotypic change in these HUCB cells was associated with specific gene expression of transcription factors for Gata-4 and $\mathrm{MEF} 2 \mathrm{C}$, and nuclear receptor transcription factors including PPAR $\alpha$, PPAR $\gamma$, RXR $\alpha$ and RXR $\beta$ [87].

Induction of differentiation of HUCB cell into cardiomyogenic cells was also achieved by culturing them in DMEM medium supplemented with fetal bovine serum, epidermal growth factor, insulin, and 5-azaytidine. HUCB cell differentiation into cardiomyocytes was detected through their expression of different cardiac muscle proteins such as troponin $\mathrm{T}$ and myosin ventricular heavy chain alpha/beta (MYHC) and specific gene expressions such as GATA4, NKX2.5, troponin I [90]. The cardiac differentiation of HUCB-derived MSCs was facilitated by 5-Azacytidine treatment, which activated extracellular signal related kinases (ERK), but not protein kinase C [91]. Furthermore, sphigosine-1 phosphate (S1P), a native circulating bioactive lipid metabolite, promoted the differentiation of HUCB MSCs into cardiomyocytes under cardiac myocytes conditioning medium (CMCM). A cardiomyocyte-like shape, and expression of a-actinin and myosin heavy chain (MHC) proteins were both observed in CMCM or $\mathrm{CMCM}+\mathrm{S} 1 \mathrm{P}$ culturing groups after 5 days of culturing, revealing that only the cells in $\mathrm{CMCM}+\mathrm{S} 1 \mathrm{P}$ culture condition were able to form cardiomyocyte-like action potential and voltage gated currents [84]. Several other studies support the differentiation potential of HUCB cells $[7,38,39,49,85,91-95]$.

Cardiomyocyte regeneration has also been induced via direct injection of HSCs [13] while cardiomyocyte differentiation has been stimulated via co-culturing with adipose tissue-derived cells [89]. Transplanted HUCB cells express cardiac-specific markers troponin I and cardiac myosin, suggesting differentiation into cardiomyocytes. Additionally, this HUCB-adipose cell co-culturing system reconstituted infarcted myocardium more efficiently than non-co-cultured cells [52]. Of note, the induction of HUCB cells to differentiate into cardiomyocytes has been shown to exert much more improved functional effects over non-differentiated cells in vitro and after transplantation $[52,85-87,89]$.

While many studies present positive results following transplantation of SCs derived from the HUCB or bone marrow $[97,98]$, this therapy is being questioned, specifically for the cells' transdifferentiation potential $[52,73,99]$. HSCs labeled with enhanced green fluorescent protein exhibited no visible transdifferentiation into cardiomyocytes, nor any significant increase in cardiomyocytes between cell grafted hearts and sham hearts [99]. Furthermore, there is no evidence of cardiomyocyte differentiation of HUCB cells injected post MI either via IV injection or IC delivery $[56,98]$. A more recent study showed low frequency levels of differentiation of HUCB MSCs, suggesting they are not ripe for infarct repair [100]. A study comparing the results of differentiated versus non-differentiated cells vis-à-vis revealed no significant difference in cardiac improvement between the two groups [101]. While these studies have questioned the use of these cells, they also suggest that perhaps the therapy is not entirely dependent on cellular cardiomyoplasty. An in vivo model revealed bone-marrow transplanted cells fused with cardiac muscle [92], suggesting that this fusion of host and transplanted cells may result in genetic transfer and thus rejection. A more recent study analyzed HUCB CD34+ cells co-cultured with neonatal ventricular myocytes for the presence of cardiomyocyte properties using a reporter gene system to determine whether cardiac transformation is due to differentiation of the cells or cellular fusion. Interestingly, this co-culturing system led to cell fusion, and therefore the cells expressed the myocyte features by accumulating the cardiac physiological genetic properties [90]. However, equally compelling evidence has refuted the notion of cell fusion, in that gender-specific bone marrow-derived cell grafts in experimental mouse MI revealed male-originated cells, ruling out cell fusion [93]. Due to these inconsistencies, future studies are warranted to clarify whether cellular cardiomyoplasty truly improves cardiac function following HUCB transplantation into the infarcted myocardium.

\section{Angiogenesis}

Another possible reparative mechanism is SC-induced angiogenesis in the ischemic area after MI. Numerous studies have shown that transplanted HUCB cells increased the neovascularization in the infarcted myocardial, and improved cardiac function $[38,43,45$ $47,49,58,64,65,102]$. This neovascularization is suggested to trigger the native and endogenous cells of the myocardium to proliferate and regenerate, as well as to protect against the apoptosis of the ischemic regions. A major promoter of this neovascularization is HO- 1 , a known cytoprotective enzyme in angiogenesis, paired with carbon dioxide, which is demonstrated to influence cardiac regeneration post MI [103]. The $\mathrm{CO}_{2}$ aids in vasculogenesis by activating c-kit+ stem/progenitor cells and increasing the differentiation of SCs to form new arteries and cardiomyocytes through the creation of growth factor HIF-1 $\alpha$, SDF$1 \alpha$ and vascular endothelial growth factor-B (VEGF-B) expression. However, the HO-1 relies on the $\mathrm{CO}_{2}$ to promote angiogenesis by inducing SDF-1 $1 \alpha$ expression only, indicating that $\mathrm{HO}-1$ and $\mathrm{CO}$ have potential to enhance cardiac regeneration [103]. The graft deposition may influence the resulting neovascularization in that HUCB-derived EPCs following transplantation were ingrained in the myocardium wall which was found to display robust neovascularization, suggesting that transplanting the cells into the capillaries could induce revascularization [105]. These studies altogether support that angiogenesis may mediate the improved cardiac function following transplantation of HUCBderived SCs.

\section{Paracrine Effects}

Paracrine effects refer to communication between adjacent cells mediated by the action of regulatory molecules, such as growth factors and cytokines. These effects may play a crucial role in improving left 
ventricular function following SC transplantation. Much evidence supports the idea that paracrine factors from SCs transplanted into the myocardium contribute to left ventricular remodeling and function $[39,105,106]$.

Increased vascular endothelial growth factor (VEGF) mRNA expression was detected at 7 and 27 days post HUCB cell transplantation, which was found to coincide with increased microvasculature near the infarct boundaries [50]. Additional angiogenic factor expression (fibroblast growth factor, VEGF, and SC homing factor SDF-1) was observed in engrafted MSCs two weeks post transplantation, increasing capillary density $40 \%$. The left ventricle exhibited an improved contractile function at eight weeks post transplantation, suggesting that growth factor secretion improved cardiac function [105]. Enhancing the expression of Ang1 and VEGF in HUCB CD34+ cells resulted in a further reduction of infarct volume and robust increment in capillary density, suggesting further the role of paracrine effect in improved cardiac function [49]. This initial paracrine effect was also shown to trigger a multitude of therapeutic pathways, in that by increasing angiogenesis, reducing collagen content and thus changing the extracellular matrix, it culminates with an enhanced recruitment of endogenous myofibroblasts [49].

Similarly, the HUCB-mediated paracrine effect is exerted by bone marrow-derived MSCs co-injected with adeno associated virus (AAV) expressing VEGF, which led to improved therapeutic effects characterized by reduced infarct volume, recovery of cardiac function, neovascularization, and increased MSC survival 50-fold [106]. However,MSC differentiation into cardiomyocytes was not detected, and only a few surviving MSCs were observed when singularly injected [106]. Nonetheless, despite this low MSC differentiation potential and graft persistence, infarct size was still reduced, suggesting that the MSC-secreted paracrine factors is likely the alternative mechanism of functional repair in MI Indeed, GATA-4 increased MSC survival, promoted neovascularization, and enhanced cardiac recovery by upregulating IGF-1 and VEGF in the MSCs [39].

The overexpression of the angiogenic factors not only promoted neovascularization, but improved several parameters of cardiac function including fractional shortening, tissue velocity, and wall motion score index [94]. In tandem with increased neovascularization, elevated angiogenic factors promoted myogensis, vasculogenesis, and anti-apoptotic effects within the injured myocardium, the major deposition site of the transplanted SCs. The latter is indicative that both migration and paracrine secretory properties of the SCs may interact to produce therapeutic benefit in MI. This combined therapeutic pathway involving cell migration and paracrine secretion is also shown to rescue the scarred tissue as evidenced by improved cardiac function at 4 weeks post MSC injection. However, 6 weeks post injection, no benefits of myogenic differentiation were observed [7], suggesting that cell migration at the early stage is important for treating MI.

\section{Anti-Inflammation}

Transplanted HUCB cells have the ability to attenuate the ischemic-induced inflammatory/immune response in the infarcted heart, representing another intriguing potential repair mechanism [51,105,108]. Increasing evidence indicates that HUCB-derived MSCs secrete a variety of pro- and anti- inflammatory cytokines that directly act to limit deleterious and permanent endogenous inflammation of the heart [105]. Similarly, injection of HUCB cells into infarcted myocardium of non-immunosuppressed rats, within $2 \mathrm{~h}$ or at $24 \mathrm{~h}$ following left anterior descending coronary artery (LAD) occlusion, resulted in reduction of infarction sizes 1 month later [51], concomitant with a significant change in myocardial concentrations of tumor necrosis factor-alpha (TNF-alpha), monocyte/macrophage chemoattractant protein (MCP-1), monocyte inflammatory protein (MIP), and interferon-gamma (INF-gamma) as compared to control animals at 2, 6, 12, and 24h after coronary occlusion [51].

More recently, an investigation of the immunological/inflammatory responses by the host to implanted bone marrow mesenchymal SCs (BMSC), cultured on silk fibroin/hyaluronic acid (SH) patches [108], suggests that modulation of inflammatory responses is achievable through transplantation of HUCB-MSC, which display similar stem cell phenotypic and functional properties as BMSC. In response to BMSCs, expression of CD68 (macrophage marker) was not detected in the MI zones exposed to the $\mathrm{SH}$ patches when compared to non-SH patchexposed MI zones. The SH patches provided an anti-inflammatory effect, and application of SCs with $\mathrm{SH}$ significantly improved wall thickness of LV, had a high viability of delivery of BMSC, largely reduced apoptosis, and significantly promoted neo-vascularization and stimulated VEGF secretions and various other paracrine factors [108] . That HUCB-MSC may also modulate inflammatory responses could attenuate the secondary wave of ischemic damage after the MI.

While these represent some of the more widely accepted MI mechanisms, either a singular or combination of known and unknown factors, identifying the exact mode of action underlying the functional effects of cell therapy in MI requires more investigations. Future experiments should consider these therapeutic pathways in designing HUCB transplantation therapy for MI.

\section{Delivery Routes and Preclinical Outcomes}

Although published data about transplantation of HUCB cells into the heart is still in its early stages, animal models of MI have already demonstrated that several delivery routes can be used to successfully transplant these cells effectively and safe. Among the most common delivery methods for transplantation are intramyocardial, intravenous (IV), and intracoronary (IC) injections [38, 46,51,52,54, 109].

\section{Intramyocardial injection}

Intramyocardial injection are injection performed directly into the myocardium $[38,46,51,52]$. This direct administration of cells into the damage heart muscle has proven to be more effective than indirect methods. Comparing indirect and direct delivery methods, intramyocardial injection significantly reduced the infarct size area as compared to indirect methods of HUCB cell delivery [110]. Although this method is preferred, there are some disadvantages that need to be taken into consideration before delivering the cells. This procedure only allows a very small amount of cell to be delivered, and it is an invasive procedure. Intramyocardial injections require open heart surgery in order to deliver the cells directly to the infarcted heart [54]. Additionally, there is the risk for possible arrthymogenicity.

Even though this delivery method has some disadvantages, preclinical studies have shown promising results for myocardial repair utilizing this method. Improved diastolic pressure and cardiac function were achieved in an animal model of intramyocardial injections of HUCB cells of different populations, such as CD34+KDR+ or CD34+KDR- cells on non-obese diabetic-severe combined immunodeficiency mice or NOD-SCID mice at 24hours after LAD. About 200,000 cells of CD34+KDR+ significantly improved left ventricular diastolic pressure after MI relative to control injection of PBS or mononuclear cells. Histology analyzes reveal limited number of 
newly formed cardiomyocytes in the area of injury. Overall, this study was able to successfully use direct method of delivery in identifying the therapeutic subfraction within the CD34+ population [38].

Similar studies have supported the therapeutic role of transplanting HUCB cells directly into the heart, showing improvements of ventricular function following intramyocardial injection of HUCB cells after MI. Using different immunofluorescent tags, HUCB cells injected directly into the heart survived in the myocardium, increased neovascularization and improved cardiac function at 4 weeks after transplantation. These results suggest the large therapeutic potential of HUCB cells when delivered directly to the damaged myocardium $[41,46]$.

Another study injecting HUCB cells directly into the damaged myocardium was found to improve left ventricular function in a rat model of MI [40]. About $10^{6} \mathrm{HUCB}$ mononuclear progenitor cells were injected into the myocardium 1 hour post LAD ligation. There were no significant differences in ejection fraction after 1 month between the group injected with HUCB and PBS. However, after 3 and 4 months, the anteroseptal wall, from HUCB-treated rats, was significantly thicker relative to control rats. In addition, a significantly robust reduction in infarct size was achieved in the heart of HUCB injected rats [40], showing the long term effects of HUCB transplantation.

Arteriole and capillary density increased at 4 weeks after transplantation of unrestricted human somatic stem cells (USSCs) derived from the HUCB into the myocardium. To determine whether these cells truly enhanced regeneration through differentiation, markers like cardiac troponin-T, smooth muscle actin, and von Willebrand factor were used for analysis. USSCs were shown to express each marker, indicative of cellular differentiation into cardiomyocytes, smooth muscle cells, and endothelial cells respectively. Using the direct delivery of USSCs, this study supports the theory of cardiomyoplasty [49].

Additionally, transplanting HUCB cells, using direct delivery method of intramyocardial injection, a study was able to support the angiogenic potential of HUCB cells after MI as a possible repair mechanism. In this study, HUCB cells were transplanted immediately after MI. After 4 weeks from transplantation, there was a significant increase of the vascular endothelial growth factor or VEGF 164 and VEGF 188 [50]. Intramyocardial injections of HUCB cells were also found to attenuate the inflammatory immune response after MI [51]. To further augment the host inflammation associated with MI, a collagen matrix with HUCB cells grafted directly onto the infarcted area improved survival as well as cardiomyoplasty [53].

Studies that are more recent further support the intramyocardial injection as an effective cell delivery system. HUCB cells were injected into one or two positions of the myocardium near the edge of the infarct area in rats [110]. Three weeks after implantation, HUCB cells were detected using nuclear staining primarily in the border of the infarct area, suggesting that the cells have the potential to survive for at least three weeks following implantation. As shown in earlier studies, these results also reveal amelioration of cardiac functioning after direct transplantation of HUCB cell into the myocardium after [42-44].

Moreover, in order to find an optimal dose for the direct delivery method, an MI rat model was used. Rats were injected with HUCB cells into the peri-infarct zone in a dose-dependent manner in a series of $6 \times 10 \mu \mathrm{L}$ injections of $1 \times 10^{5}$ (considered the low dose, or LD), and $1 \times 10^{6}$ (considered the high dose, or HD) of HUCB cells [59]. The effects of the cells were analyzed from 5 to 28 days following transplantation. At day 5, there were no differences across the groups. However, the cells considerably contributed to the maintenance of left ventricular (LV) structure based on percent of fibrosis, and a number of other measurements. On day 28 , capillary density related to myocardial neovascularization was enhanced in both dosage groups, as was left ventricular wall motion in comparison to the non-treated group. On day 23, fractional shortening (FS) was higher in the HD group, but not significantly different than the LD group. In contrast, a lower regional wall motion score (RWMS) was observed in the LD and HD groups indicating a better protection in the treatment groups. Analysis of $+\mathrm{dP} / \mathrm{dt}$ to assess left ventricular contractility revealed that the HD group levels were significantly greater than the LD group, with even lower levels found among the untreated groups [112]. After four weeks, left ventricular end diastolic pressure (LVEDP) was lower in both HD and LD groups. In addition to suggesting the cells improved cardiac functioning, the study found that HUCBs differentiated into human cardiomyocytes (CMCs) in a dose-dependent manner [112]. Altogether, these studies using the direct delivery method to transplant HUCB cells demonstrated promising results for the treatment and repair of the failing heart after MI.

\section{Intravenous injection}

Intravenous injection of HUCB cells offers a less invasive cellular delivery system than intramyocardial injection. Studies using animal models of stroke have revealed that transplanted cells through, systemic administration, are able to migrate to the ischemic site of injury, and may contribute to the improvement of behavioral deficits [33-36]. However, systemic administration may cause these SCs to aggregate in different organs before reaching the injured site. In fact, it has been shown that only a fraction of these cells reach the site of injury due to the aggregation of the cells within the microvasculature of the liver, lungs, and lymphoid tissue [54]. Additionally, shortness of breath and death due to pulmonary embolisms has been noted with this procedure [112]. Despite some controversy, IV administration of HUCB cells is still studied by many pre-clinical scientific groups to further asses its beneficial effects as an indirect route of delivery and to further improve its outcomes $[42,43,48,51]$.

In a study injecting HUCB cells into the tail vein of mice induced with MI from an LAD ligation, cell migration, cell survival and infract size were characterized in order to assess the efficacy of IV delivery [42]. Organ analysis of mice showed detectable levels of hDNA after 24 hours, 1 day, and 3 weeks following transplantation; no sham animals were observed with hDNA. However, hDNA was not completely detected in all mice with MI (only 10/19). MI mice showed an abundance of HUCB cells in the perivascular interstitium, while having a reduced infarct volume compared to the sham animals. Furthermore, there was significant infarct reduction in the MI as well as $20 \%$ higher capillary density around the infarct area border. There was no decrease in collagen deposition between the two groups. Co-localization of HNA or HLA-I with GATA-4 or Connexin 43 showed no evidence of HUCB mononuclear cells differentiation into cardiomyocytes. The expression of SDF-1 mRNA on the MI+ mouse was approximately 7-fold higher than the MI- group [42]. In a parallel study, the migration and survival of HUCB mononuclear cells following IV transplant were trackedand revealed cell aggregation, but it is not consistent in all injected mice [43]. Cell migration to the heart was detected only in MI mice and not sham mice, proposing a signal-induced migration by damaged or injured tissue [43].

Another cell tracking study demonstrated the migration of HUCBderived CD133+ cells when IV delivered at seven days after permanent 
coronary artery ligation in rats [48]. One month post transplant, lateral ventricle fractional shortening improved relative to control mice. Only control animals presented thinning of the anterior wall of the heart. Following tracking the migration of the cells, it was revealed they colonized and survived in the infarcted myocardium. The cells in the nearby vessel walls were determined to be of human origin, while scar tissue indicated autologous myofibroblasts and alpha-smooth muscle. This study supports IV administration as an adequate strategy for HUCB cell transplantation, allowing effective migration of the cells to the area of injury where they subsequently induce autologous differentiation for repair of infarcted myocardium [48].

Another important factor for IV delivery of HUCB cells is timing, notably that endogenous signals are able to guide the migration of the cells to the infarct area. An in vivo study found that the greatest migration of IV administered cells to MI region was between 2 hours to 24 hours after LAD occlusion [51]. Protein characterization revealed increase cytokine and chemokine production in this time. In particular, stromal cell derived fator-1 (SFD-1) was highly up-regulated in the infarcted area of the myocardium. SFD-1 is a chemokine that attracts circulating SCs via CXCR4, integrating activation of integrins in the vasculature [78].

Accumulating preclinical studies have shown the significant clinical relevance that IV administration of HUCB cells has for the treatment and repair of the infarcted heart. In a recent study, the effectiveness of IVdelivery method for HUCB cell base therapy has been analyzed at different points in time following MI [113]. Four transplants of equal amounts were IV administered at days 1, 5, 10, and 30 following the MI, and the effects of the cells were analyzed using echocardiographic assessment. It was found that in 5 and 10-days following transplants, rats had significantly increased left ventricular ejection fraction (LVEF) as compared to the control group, whereas the LVEDD and LVESD levels were significantly smaller in the treatment group. Moreover, left ventricular wall thickening was most notable and significant in the 10day transplantation group. Scar tissue area was reduced in the 5- day group and in the 10-day group relative to the PBS control group. At both time points, microvascular density was larger than the control group, with the 10 day point having the larger area. VEGF levels were higher in the 10 day group than any other as well. At this 10 day time point, the largest concentration of HUCB cells within the infarct area was found, which correlated with the higher VEGF levels [113]. Future studies are warranted to assess the long term potential of the reparative capacity of HUCB cells.

Intravenous delivery of different types of cells derived from HUCB was also examined; in particular comparing the efficacy of injecting post MI expanded HUCB cells with that of non-expanded HUCB cells. Two days post MI, $10^{6}$ expanded and non-expanded HUCB cells were injected into the tails of rats. No detectable differences between the groups were observed at two days post injection, and there was no significant difference in cardiac function at two weeks (analyzed using LVEF). ( $61 \pm 5.9 \%$ and $64 \pm 4.1 \%$, respectively). Four weeks post IV administration, cardiac function appeared to be improved, but there was still no statistical difference [114]. This study suggests that there were no functional differences between expanded versus nonexpanded HUCBs. Although more studies are needed to further test the efficacy of expanded SCs, these results showed that HUCB cells can be expanded in vitro without losing their functional activity $[114,115]$.

Despite negative controversial results, especially the formation of embolus using IV administration of HUCB cells, these studies support the concept that the minimally invasive IV administration faciliated
HUCB-derived SCs to migrate to infarcted area and ameliorate cardiac function [78].

\section{Intracoronary delivery}

SC transplantation can also be achieved using the IC delivery method. This method allows delivery of SCs directly into the damaged myocardium without passing through systemic circulation However, the possibility of cell aggregation is very high in IC injection, especially if a large amount of cells are delivered in the catheter $[60,116]$ Yet, over the last decade, several studies have shown a good safety profile of IC injection of bone marrow and peripheral blood-derived mononuclear cells [42,44,54,116-119].

The IC route of SC delivery is the least commonly used in MI animal models. After 5 weeks from treatment, it was concluded that LV was not ameliorated, infarcted area was not reduced, and surviving cells did not express cardiomyocytes or endothelial markers [98]. Histological analyses revealed that IC injection caused microinfarctions due to obstruction of blood vessels likely due to the large amount of cells injected $\left(10^{8}\right)$ [98]. More pre-clinical research needs are warranted to evaluate the efficacy and safety of IC delivery of HUCB for transplantation in MI.

\section{HUCB, Gene Therapy, and Other Novel Techniques}

As noted above, HUCB cells for myocardial repair and revascularization following MI offers a glimpse of hope as an alternative therapeutic option. A major caveat in realizing the successful outcome of HUCB transplantation for MI is overcoming delivery of the cells or the cells' nutritive substances (angiogenic, trophic and anti-inflammatory factors) to the non-conducive environment of the ischemic heart. Genetically modifying SCs may circumvent the technical problems of cell delivery and hostile environment associated with ischemic diseases [95,120-123].

Previous studies on SC therapy for MI reveal potential for the combined use of gene therapy with HUCB cells. Adeno associated viral vectors (AAVs) were used to transduce angiogenic factors to the heart. Human ang1-alone, VEFG (165) alone or a combination with AAVs were transduced to CD34+ cells and injected intramyocardially immediately after ligation of the left anterior descending coronary artery in male SCID mice to infarcted ventricles [47]. Four weeks following gene delivery, protein analysis confirmed the upregulation of ang- 1 and VEGF or both in the CD34+ transduced groups. The results showed a significant decrease of the infarct size, and a significant increase in capillary density relative to control (treatment with CD34+ alone) in all treatment groups (AAV-ang-1, AAV-VEGF, or AAVang-1+VEGF). In terms of cardiac functioning, echocardiography assessment showed significant amelioration on cardiac performance [47]. The results demonstrated the utility of viral vectors and SCs for the repair of myocardial infarcted hearts.

Additional gene-based techniques have been explored to improve the therapeutic potential of HUCB MSCs [123]. In order to effectively engraft these cells, spherical three-dimensional (3D) bullets made of cultured cells in anchored-deprived media were created to deliver MSCs to the heart. This treatment was shown to improve left ventricular contractility, lessen fractional shortening, and decrease and prevent pathologic left ventricular dilation when compared to single cell treatment [123]. The efficacy of MSCs increased once the spherical bullets formed, allowing for cell to cell interaction, inducing E-cadherin, which is essential to the bullet formation, activating and initiating the cascade of proliferative angiogenic pathways and increasing the 
endogenic potential of the cells. Overexpression of E-cadherin revealed secretion of VEGF, which probably induces the angiogenic pathways. The same concept was used for core-shell bodies, where MSCs are combined with endothelial cells from the umbilical cord vein. Results revealed MSCs differentiated into smooth muslces and there was a robust excretion of VEGF [124]. Both of these concepts represent a new field of genetic manipulation for enhancing the therapeutic effects of HUCB-derived cells.

Microporation has also been employed to increase efficacy of the MSCs. The technique transduces plasmid DNA into the HUCB-derived cells. Minimal cell damage occurred when brain derived neurotrofic factor (BDNF) was successfully transduced via microporation, wherein immunophenotype, proliferation, and differentiation activity of HUCBMSCs was not affected when migrating toward brain cancer cells [95]. The study highlights the use of a reliable transduction technique, which further studies could use to transfer trophic factors to muscle tissue of the failing heart ventricles without altering the beneficial effects of SC transplantation therapy.

Although the translational potential of genetic manipulation of HUCB cells is in its infancy, it stands as an innovative approach in overcoming limitations of cell delivery. Further studies are warranted to test the safety and efficacy of combined gene and cell therapy.

\section{Conclusion}

Cell-based remains an experimental treatment for MI. Historically, the use of HUCB cells is circumvents the ethical concerns associated with embryonic SCs use due to their source and method of acquisition. Animal models of hearing loss, Parkinson's disease, Alzheimer's disease, stroke, and Huntington's disease have also evaluated the therapeutic medical value of HUCB cells. Due to the uniqueness of the diseases, tailored cell therapies to target each disorders may be required to achieve clinical improvement [34-36,38,40,122]. Several pre-clinical studies strongly support the use of HUCB cells for the therapeutic treatment of MI. However, additional research is still necessary to establish HUCB cells as a safe and effective cell-based approach to for use in MI patients.

Many studies emphasize the importance of the optimal timing of HUCB administration, as this timing assures higher rates of engraftment, survival, and differentiation compared. Transplantation acutely after the initial injury could decrease cell survival due to the release of inflammatory cytokines, while transplantation at the chronic stage could mean rampant scarring that may prevent graft-host signaling pathways necessary for directed cell migration and differentiation, as well as appropriate paracrine secretion. A careful examination of the literature reveals that transplanting HUCB cells as early as 24 hours after MI ameliorates ventricular function and contractility [38,40$42,47,49,50]$, and, on the other side, cell transplantation even at 4 weeks post MI has been shown to afford a general improvement of heart function $[46,49]$. Therefore, it is necessary to conduct vis-à-vis comparative studies in order to find an optimal time frame with the most therapeutic benefit that has direct clinical application.

Disagreement also exists over the optimal number of transplanted cells: the studies show both a variety of doses, and quantity of transplanted cells $[38,40-43,45-53]$. It is essential to determine an optimal dose response in an effort to standardize the HUCB dosage, which should coincide with high therapeutic value for MI and ventricular repair in cardiac failure. Table 1 organizes the current studies by dosage.
Although HUCB has less immunogenicity issues, graft rejection needs to be monitored to ensure successful transplant outcome. In most studies, HUCB cell transplantation revealed a very attractive option as the treatment was effective in MI rat models without the need for immunosuppression [40-43,45,47,48]. However, studies tended to only follow the fate of the HUCB grafts for very short time periods, from 2 weeks to 4 months being the average time points, suggesting the need to observe the cells under longer-time periods in order to fully determine the need for immunosuppression and the presence of functional recovery. An additional concern and important study that needs to be performed is a long-term follow up of HUCB migration as the cells could move through the heart vasculature to other organs.

Finally, while SC engineering may enhance tissue repair capabilities, their ability to migrate to the target tissue and their capacity to differentiate or exert paracrine effects require elucidation to harness cellular and molecular pathways of exogenous and endogenous repair mechanisms. Although still a novel technique, studies support the notion that gene therapy and HUCB cells could overcome many transplantation challenges or improve the HUCB potential by either enhancing or ameliorating the delivery of trophic factors or by increasing their differentiation potential for the treatment of ischemic diseases as MI and stroke [47,94,95,106,123]. However, gene therapy itself may pose a novel set of safety and efficacy issues that require similar optimization and standardization preclinical studies.

HUCB cells continue to garner preclinical data furthering our basic science of stem cell biology but also providing insights into the translation of cell-based therapeutics for the amelioration of MI and other ischemic disorders.

\section{Acknowledgements}

Sources of Financial Support: CVB is supported by the National Institutes of Health, the National Institute of Neurological Disorders and Stroke 1R01NS071956-01, the James and Esther King Foundation for Biomedica Research Program, SanBio Inc., Celgene Cellular Therapeutics, KM Pharmaceutica Consulting, and NeuralStem Inc. The funders had no role in study design, data collection and analysis, decision to publish, or preparation of the manuscript.

\section{Authors' contribution}

Conceived the theme of the paper: CVB. Analyzed and interpreted the literature: SAA, NF, MS, NLW, MB, JP, NM, AJS, AS, MC, MP GF, MF, LS, CGP, TD, KS, NT, PRS, YK LWM, CVB. Wrote the paper: SAA, NF, MS, NLW, LWM, CVB.

\section{Conflicts of Interest}

CVB and PRS serve as consultants of Saneron-CCEL Therapeutics, Inc and Cryo-Cell International, Inc., and PRS is a co-founder of Saneron-CCEL Therapeutics, Inc., and CVB and PRS have patent and patent applications in this area.

\section{References}

1. Cleland JG, Khand A, Clark A (2001) The heart failure epidemic: exactly how big is it? Eur Heart J 22: 623-626.

2. Redfield MM (2002) Heart failure: an epidemic of uncertain proportions. N Eng J Med 347: 1442-1444.

3. George JC (2010) Stem cell therapy in acute myocardial infarction: a review of clinical trials. Transl Res 155: 10-19.

4. Henning RJ, Dennis S, Sawmiller D, Hunter L, Sanberg P, et al. (2012) Human umbilical cord blood mononuclear cells activate the survival protein Akt in cardiac myocytes and endothelial cells that limits apoptosis and necrosis during hypoxia. Transl Res 159: 497-506.

5. Beltrami AP, Urbanek K, Kajstura J, Yan SM, Finato N, et al. (2001) Evidence that human cardiac myocytes divide after myocardial injection. N Engl J Med 344: 1750-1757. 
Citation: Acosta SA, Franzese N, Staples M, Weinbren NL, Babilonia M, et al. (2013) Human Umbilical Cord Blood for Transplantation Therapy in Myocardial Infarction. J Stem Cell Res Ther S4: 005. doi:10.4172/2157-7633.S4-005

Page 9 of 11

6. Quaini F, Urbanek K, Beltrami AP, Finato N, Beltrami CA, et al. (2002) Chimerism of the transplanted heart. N Engl J Med 346: 5-15.

7. Dai W, Hale SL, Kloner RA (2005) Stem cell transplantation for the treatment of myocardial infarction. Transpl Immunol 15: 91-97.

8. Soonpaa MH, Koh GY, Klug MG, Field LJ (1994) Formation of nascent intercalated disks between grafted fetal cardiomyocytes and host myocardium. Science 264: 98-101.

9. Parker SJ, Didier DN, Karcher JR, Stodola TJ, Endres B et al. (2012) Bone marrow mononuclear cells induce beneficial remodeling and reduce diastolic dysfunction in the left ventricle of hypertensive SS/MCWi rats. Physio Genomics 44: 925-933.

10. Reinecke H, Zhang M, Bartosek T, Murry CE (1999) Survival, integration, and differentiation of cardiomyocyte grafts: a study in normal and injured rat hearts. Circulation 100: 193-202.

11. Yu G, Borlongan CV, Stahl CE, Yu SJ, Bae E, et al. (2008) Transplantation of human umbilical cord blood cells for the repair of myocardial infarction. Med Sci Monit14: RA163-172.

12. Zeng H, Li I, Chen LX (2012) Overexpression of angiopoietin-1 increases CD133+/c-kit+ cells and reduces myocardial apoptosis in $\mathrm{db} / \mathrm{db}$ mouse infarcted hearts. PLoS One 7: e35905.

13. Orlic D, Kajstura J, Chimenti S, Jakoniuk I, Anderson SM, et al. (2001) Bone marrow cells regenerate infarcted myocardium. Nature 410: 701-705.

14. Fang $\mathrm{CH}$, Jin J, Joe JH, Song YS, So BI, et al. (2012) In Vivo Differentiation of Human Amniotic Epithelial Cells into Cardiomyocyte-Like Cells and Cell Transplantation Effect on Myocardial Infarction in Rats: Comparison with Cord Blood and Adipose Tissue-Derived Mesenchymal Stem Cells. Cell Transplan 21: 1687-1696.

15. MacDonald DJ, Luo J, Saito T, Duong M, Bernier PL, et al. (2005) Persistence of marrow stromal cells implanted into acutely infarcted myocardium: observations in a xenotransplant model. J Thorac Cardiovasc Surg 130: 1114-1121.

16. Amado LC, Saliaris AP, Schuleri KH, St John M, Xie JS, et al. (2005) Cardiac repair with intramyocardial injection of allogeneic mesenchymal stem cells after myocardial infarction. Proc Natl Acad Sci U S A 102: 11474-11479.

17. Hassan F, Meduru S, Taguchi K, Kuppusamy K, Mostafa M, et al. (2012) Carvedilol enhances mesenchymal stem cell therapy for myocardial infarction via inhibition of caspase-3 expression. J Pharmacol Exp Ther 343: 62-71.

18. Cerrada I, Ruiz-Sarui A, Carrerro R, Trigueros C, Dorronsoro A, et al (2012) Hypoxia-inducible factor 1 alpha contributes to cardiac healing in mesenchymalstem cells mediated cardiac repair. Stem Cells Dev 22: 501-511.

19. Gaebel R, Furlani D, Sorg H, Polchow B, Frank J, et al. (2011) Cell origin of human mesenchymal stem cells determines a different healing performance in cardiac regeneration. PLoS One 6: e15652.

20. Wang JS, Kovanecz I, Vernet D, Nolazco G, Kopchok GE, et al. (2012) Effects of sildenafil and/or muscle derived stem cells on myocardial infarction. J Transl Med 10: 159.

21. Dib N, Michler RE, Pagani FD, Wright S, Kereiakes DJ, et al. (2005) Safety and feasibility of autologous myoblast transplantation in patients with ischemic cardiomyopathy: four-year follow-up. Circulation 112: 748-1755.

22. Konoplyannikov M, Haider K, Lai VK, Ahmed RP, Jinag S, et al. (2012) Activation of diverse signaling pathways by ex-vivo delivery of multiple cytokines for myocardial repair. Stem Cells Dev 22: 204-215.

23. von Wattenwyl R, Blumenthal B, Heilmann C, Golsong P, Poppe A, et al (2012) Scaffold-based transplantation of vascular endothelial growth factoroverexpressing stem cells leads to neovascularization in ischemic myocardium but did not show a functional regenerative effect. ASAIO J 58: 268-274.

24. Povsic TJ, O'Connor CM, Henry T, Taussig A, Kereiakes DJ, et al. (2011) A double-blind, randomized, controlled, multicenter study to assess the safety and cardiovascular effects of skeletal myoblast implantation by catheter delivery in patients with chronic heart failure after myocardial infarction. Am Heart J 162: 654-662.

25. Pompilio G, Cannata A, Peccatori F, Bertolini F, Nascimbene A, et al (2004) Autologous peripheral blood stem cell transplantation for myocardial regeneration: a novel strategy for cell collection and surgical injection. Ann Thorac Surg 78: 1808-1812.

26. Yan F, Yao Y, Chen L, Li Y, Sheng Z, et al. (2012) Hypoxic Preconditioning
Improves Survival of Cardiac Progenitor Cells: Role of Stromal Cell Derived Factor-1a-CXCR4 Axis. PLoS One 7: e37948.

27. Dawn B, Stein AB, Urbanek K, Rota M, Whang B, et al. (2005) Cardiac stem cells delivered intravascularly traverse the vessel barrier, regenerate infarcted myocardium, and improve cardiac function. Proc Natl Acad Sci U S A 102 3766-3771.

28. Mitchell AJ, Sabondjian E, Blackwood KJ, Sykes J, Deans L, et al. (2013) Comparison of the myocardial clearance of endothelial progenitor cells injected early versus late into reperfused or sustained occlusion myocardial infarction Int J Cardiovasc Imaging 29: 497-504.

29. Scheubel RJ, Zorn H, Silber RE, Kuss O, Morawietz H, et al. (2003) Agedependent depression in circulating endothelial progenitor cells in patients undergoing coronary artery bypass grafting. J Am Coll Cardiol 42: 2073-2080.

30. Vasa M, Fichtlscherer S, Aicher A, Adler K, Urbich C, et al. (2001) Number and migratory activity of circulating endothelial progenitor cells inversely correlate with risk factors for coronary artery disease. Circ Res 89: E1-7.

31. Eizawa T, Ikeda U, Murakami Y, Matsui K, Yoshioka T, et al. (2004) Decrease in circulating endothelial progenitor cells in patients with stable coronary artery disease. Heart 90: 685-686.

32. Murohara T, Ikeda H, Duan J, Shintani S, Sasaki K, et al. (2000) Transplanted cord blood-derived endothelial precursor cells augment postnatal neovascularization. J Clin Invest 105: 1527-1536.

33. Vendrame M, Cassady J, Newcomb J, Butler T, Pennypacker KR, et al. (2004) Infusion of human umbilical cord blood cells in a rat model of stroke dosedependently rescues behavioral deficits and reduces infarct volume. Stroke 35 2390-2395.

34. Willing AE, Lixian J, Milliken M, Poulos S, Zigova T, et al. (2003) Intravenous versus intrastriatal cord blood administration in a rodent model of stroke. $J$ Neurosci Res 73: 296-307.

35. Borlongan CV, Hadman M, Sanberg CD, Sanberg PR, (2004) Central nervous system entry of peripherally injected umbilical cord blood cells is not required for neuroprotection in stroke. Stroke 35: 2385-2389.

36. Taguchi A, Soma T, Tanaka H, Kanda T, Nishimura H, et al. (2004) Administration of CD34+ cells after stroke enhances neurogenesis via angiogenesis in a mouse model. J Clin Invest 114: 330-338.

37. Broxmeyer HE, Lee MR, Hangoc G, Cooper S, Prasain N, et al. (2011) Hematopoietic stem/progenitor cells, generation of induced pluripotent stem cells, and isolation of endothelial progenitors from 21- to 23.5-year cryopreserved cord blood. Blood 117: 4773-4777.

38. Botta R, Gao E, Stassi G, Bonci D, Pelosi E, et al. (2004) Heart infarct in NOD SCID mice: therapeutic vasculogenesis by transplantation of human CD34+ cells and low dose CD34+KDR+ cells. FASEB J 18: 1392-1394.

39. Li H, Zuo S, He Z, Yang Y, Pasha Z, et al. (2010) Paracrine factors released by GATA-4 overexpressed mesenchymal stem cells increase angiogenesis and cell survival. Am J Physiol Heart Circ Physiol 299: H1772-1781.

40. Henning RJ, Abu-Ali H, Balis JU, Morgan MB, Willing AE, et al. (2004) Human umbilical cord blood mononuclear cells for the treatment of acute myocardial infarction. Cell Transplant 13: 729-739.

41. Hirata Y, Sata M, Motomura N, Takanashi M, Suematsu Y, et al. (2005) Human umbilical cord blood cells improve cardiac function after myocardial infarction. Biochem Biophys Res Commun 327: 609-614.

42. Ma N, Ladilov Y, Moebius JM, Ong L, Piechaczek C, et al. (2006) Intramyocardia delivery of human CD133+ cells in a SCID mouse cryoinjury model: Bone marrow vs. cord blood-derived cells. Cardiovasc Res 71: 158-169.

43. Ma N, Ladilov Y, Kaminski A, Piechaczek C., Choi YH, et al. (2006) Umbilical cord blood cell transplantation for myocardial regeneration. Transplant Proc 38: $771-773$

44. Ma N, Stamm C, Kaminski A, Li W, Kleine HD, et al. (2005) Human cord blood cells induce angiogenesis following myocardial infarction in NOD/scid-mice. Cardiovasc Res 66: 45-54.

45. Ott I, Keller U, Knoedler M, Gotze KS, Doss K, et al. (2005) Endothelial-like cells expanded from CD34+ blood cells improve left ventricular function after experimental myocardial infarction. FASEB J 19: 992-994.

46. Kim BO, Tian H, Prasongsukarn K, Wu J, Angoulvant D, et al. (2005) Cell transplantation improves ventricular function after a myocardial infarction: a 
Citation: Acosta SA, Franzese N, Staples M, Weinbren NL, Babilonia M, et al. (2013) Human Umbilical Cord Blood for Transplantation Therapy in Myocardial Infarction. J Stem Cell Res Ther S4: 005. doi:10.4172/2157-7633.S4-005

preclinical study of human unrestricted somatic stem cells in a porcine model. Circulation 112: 196-104.

47. Chen HK, Hung HF, Shyu KG, Wang BW, Sheu JR, et al. (2005) Combined cord blood stem cells and gene therapy enhances angiogenesis and improves cardiac performance in mouse after acute myocardial infarction. Eur $\mathrm{J}$ Clin Invest 35: 677-686.

48. Leor J, Guetta E, Feinberg MS, Galski H, Bar I, et al. (2006) Human umbilical cord blood-derived CD133+ cells enhance function and repair of the infarcted myocardium. Stem Cells 24: 772-780.

49. Wu KH, Zhou B, Yu CT, Cui B, Lu SH, et al. (2007) Therapeutic potential of human umbilical cord derived stem cells in a rat myocardial infarction model. Ann Thorac Surg 83: 1491-1498.

50. Hu CH, Wu GF, Wang XQ, Yang YH, Du ZM, et al. (2006) Transplanted human umbilical cord blood mononuclear cells improve left ventricular function through angiogenesis in myocardial infarction. Chin Med J (Engl) 119: 1499-1506.

51. Henning RJ, Burgos JD, Ondrovic L., Sanberg P, Balis J, et al. (2006) Human umbilical cord blood progenitor cells are attracted to infarcted myocardium and significantly reduce myocardial infarction size. Cell Transplant 15: 647-658.

52. Yamada Y, Yokoyama S, Fukuda N, Kidoya H, Huang XY, et al. (2007) A novel approach for myocardial regeneration with educated cord blood cells cocultured with cells from brown adipose tissue. Biochem Biophys Res Commun 353: 182 188

53. Cortes-Morichetti M, Frati G, Schussler O, Duong Van Huyen JP, Lauret E, et al. (2007) Association between a cell-seeded collagen matrix and cellular cardiomyoplasty for myocardial support and regeneration. Tissue Eng 13: 2681-2687.

54. Mozid AM, Arnous S, Sammut EC, Mathur A (2011) Stem cell therapy for heart diseases. Br Med Bull 98: 143-159.

55. Smith AR, Wagner JE (2009) Alternative haematopoietic stem cell sources for transplantation: place of umbilical cord blood. Br J Haematol 147: 246-261.

56. Zhong XY, Zhang B, Asadollahi R, Low SH, Holzgreve W (2010) Umbilical cord blood stem cells: what to expect. Ann N Y Acad Sci 1205: 17-22.

57. Newman MB, Davis CD, Borlongan CV, Emerich D, Sanberg PR (2004) Transplantation of human umbilical cord blood cells in the repair of CNS diseases. Expert Opin Biol Ther 4: 121-130.

58. Newman MB, Davis CD, Kuzmin-Nichols N, Sanberg PR (2003) Human umbilical cord blood (HUCB) cells for central nervous system repair. Neurotox Res 5: 355-368.

59. Bronxmeyer HE, Srour EF, Hangoc G, Cooper S, Anderson SA, et al. (2003) High-efficiency recovery of functional hematopoetic progenitor and stem cells from human cord blood cryopreserved for 15 years. Proc Natl Acad Sci U S A 100: $645-650$

60. Gluckman E, Ruggeri A, Volt F, Cunha R, Boudjedir K, et al. (2011) Milestones in umbilical cord blood transplantation. $\mathrm{Br} \mathrm{J}$ Haematol 154: 441-447.

61. Orlic D, Girard LJ, Anderson SM, Do BK, Seidel NE (1997) Transduction efficiency of cell lines and hematopoietic stem cells correlates with retrovirus receptor mRNA levels. Stem Cells 15: 23-29.

62. McKenna D, Sheth J (2011) Umbilical cord blood: current status \& promise for the future. Indian J. Med. Res.134: 261-269.

63. Lee MW, Jang IK, Yoo KH, Sung KW, Koo HH (2010) Stem and progenitor cells in human umbilical cord blood. Int J Hematol 92: 45-51.

64. Butler MG, Menitove JE (2011) Umbilical cord blood banking: an update. J Assist Reprod Genet 28: 669-676.

65. Hows JM, Marsh JC, Bradley BA, Luft T, Coutinho L, et al. (1992) Human cord blood: a source of transplantable stem cells? Bone Marrow Transplant 9: 105108.

66. Lewis ID, Verfaillie CM (2000) Multi-lineage expansion potential of primitive hematopoietic progenitors: superiority of umbilical cord blood compared to mobilized peripheral blood. Exp Hematol 28: 1087-1095.

67. Nieda M, Nicol A, Denning-Kendall P, Sweetenham J, Bradley B, et al. (1997) Endothelial cell precursors are normal components of human umbilical cord blood. Br J Haematol 98: 775-777.

68. Wagner JE, Broxmeyer HE, Byrd RL, Zehnbauer B, Schmeckpeper B, et al.
(1992) Transplantation of umbilical cord blood after myeloablative therapy: analysis of engraftment. Blood 79: 1874-1881.

69. Wagner JE, Kernan NA, Steinbuch M, Broxmeyer HE, Gluckman E (1995) Allogeneic sibling umbilical-cord-blood transplantation in children with malignant and non-malignant disease. Lancet 346: 214-219.

70. Vaziri H, Dragowska W, Allsopp RC, Thomas TE, Harley CB, et al. (1994) Evidence for a mitotic clock in human hematopoietic stem cells: loss of telomeric DNA with age. Proc Natl Acad Sci U S A 91: 9857-9860.

71. Park DH, Lee JH, Borlongan CV, Sanberg PR, Chung YG, et al. (2011) Transplantation of umbilical cord blood stem cells for treating spinal cord injury. Stem Cell Rev 7: 181-194.

72. Ratajczak MZ, Suszynska M, Pedziwiatr D, Mierzejewska K, Greco NJ (2012) Umbilical cord blood-derived very small embryonic like stem cells (VSELs) as a source of pluripotent stem cells for regenerative medicine. Pediatr Endocrino Rev 9: 639-643.

73. Ratajczak MZ, Shin DM, Liu R, Mierzejewska K, Ratajczak J, et al. (2012) Very small embryonic/epiblast-like stem cells (VSELs) and their potential role in aging and organ rejuvenation--an update and comparison to other primitive small stem cells isolated from adult tissues. Aging (Albany NY) 4: 235-246

74. Bhartiya D, Shaikh A, Nagvenkar P, Kasiviswanathan S, Pethe P, et al. (2012) Very small embryonic-like stem cells with maximum regenerative potential get discarded during cord blood banking and bone marrow processing for autologous stem cell therapy. Stem Cells Dev 21: 1-6.

75. Gluckman E, Rocha V, Boyer-Chammard A, Locatelli F, Arcese W, et al (1997) Outcome of cord-blood transplantation from related and unrelated donors. Eurocord Transplant Group and the European Blood and Marrow Transplantation Group. N Engl J Med 337: 373-381.

76. Lu L, Shen RN, Broxmeyer HE (1996) Stem cells from bone marrow, umbilica cord blood and peripheral blood for clinical application: current status and future application. Crit Rev Oncol Hematol 22: 61-78.

77. Broxmeyer HE, Hangoc G, Cooper S, Ribeiro RC, Graves V, et al. (1992) Growth characteristics and expansion of human umbilical cord blood and estimation of its potential for transplantation in adults. Proc Natl Acad Sci U S A 89: 4109-4113.

78. Ghadge SK, Muhlstedt S, Ozcelik C, Bader M (2011) SDF-1alpha as a therapeutic stem cell homing factor in myocardial infarction. Pharmacol Ther 129: $97-108$

79. Broxmeyer HE (2005) Biology of cord blood cells and future prospects for enhanced clinical benefit. Cytotherapy 7: 209-218.

80. Malgieri A, Kantzari E, Patrizi MP, Gambardella S (2010) Bone marrow and umbilical cord blood human mesenchymal stem cells: state of the art. Int J Clin Exp Med 3: 248-269

81. Copeland N, Harris D, Gaballa MA (2009) Human umbilical cord blood stem cells, myocardial infarction and stroke. Clin Med 9: 342-345.

82. Wang F, Guan J (2010) Cellular cardiomyoplasty and cardiac tissue engineering for myocardial therapy. Adv Drug Deliv Rev 62:784-797.

83. Durrani S, Konoplyannikov M, Ashraf M, Haider KH (2010) Skeletal myoblasts for cardiac repair. Regen Med 5: 919-932.

84. Zhao Z, Chen Z, Zhao X, Pan F, Cai M, et al. (2011) Sphingosine-1-phosphate promotes the differentiation of human umbilical cord mesenchymal stem cells into cardiomyocytes under the designated culturing conditions. J Biomed Sci 18: 37.

85. Cheng F, Zou P, Yang H, Yu Z, Zhong Z (2003) Induced differentiation of human cord blood mesenchymal stem/progenitor cells into cardiomyocyte-like cells in vitro. J Huazhong Univ Sci Technolog Med Sci 23: 154-157.

86. Bonanno G, Mariotti A, Procoli A, Corallo M, Rutella S, et al. (2007) Human cord blood CD133+ cells immunoselected by a clinical-grade apparatus differentiate in vitro into endothelial- and cardiomyocyte-like cells. Transfusion 47: 280-289.

87. Cui YX, Kafienah W, Suleiman MS, Ascione R (2011) A New Methodological Sequence to Expand and Transdifferentiate Human Umbilical Cord Blood Derived CD133(+) Cells into a Cardiomyocyte-like Phenotype. Stem Cell Rev 9: $350-359$.

88. Yamada Y, Wang XD, Yokoyama S, Fukuda N, Takakura N (2006) Cardiac progenitor cells in brown adipose tissue repaired damaged myocardium. Biochem Biophys Res Commun 342: 662-670. 
Citation: Acosta SA, Franzese N, Staples M, Weinbren NL, Babilonia M, et al. (2013) Human Umbilical Cord Blood for Transplantation Therapy in Myocardial Infarction. J Stem Cell Res Ther S4: 005. doi:10.4172/2157-7633.S4-005

Page 11 of 11

89. Wu KH, Cui B, Yu CT, Liu YL (2006) Stem cells: new cell source for myocardial constructs tissue engineering. Med Hypotheses 67: 1326-1329.

90. Avitabile D, Crespi A, Brioschi C, Parente V, Toietta G, et al. (2011) Human cord blood CD34+ progenitor cells acquire functional cardiac properties through a cell fusion process. Am J Physiol Heart Circ Physiol 300: H1875-1884.

91. Qian Q, Qian H, Zhang X, Zhu W, Yan Y, et al. (2012) 5-Azacytidine induces cardiac differentiation of human umbilical cord-derived mesenchymal stem cells by activating extracellular regulated kinase. Stem Cells Dev 21: 67-75.

92. Nygren JM, Jovinge S, Breitbach M, Sawen P, Roll W, et al. (2004) Bone marrow-derived hematopoietic cells generate cardiomyocytes at a low frequency through cell fusion, but not transdifferentiation. Nat Med 10: 494-501.

93. Kajstura J, Rota M, Whang B, Cascapera S, Hosoda T, et al. (2005) Bone marrow cells differentiate in cardiac cell lineages after infarction independently of cell fusion. Circ Res 96: 127-137.

94. Das H, George JC, Joseph M, Das M, Abdulhameed N, et al. (2009) Stem cell therapy with overexpressed VEGF and PDGF genes improves cardiac function in a rat infarct model. PLoS One 4: e7325.

95. Lim JY, Park SH, Jeong CH, Oh JH, Kim SM, et al. (2010) Microporation is a valuable transfection method for efficient gene delivery into human umbilical cord blood-derived mesenchymal stem cells. BMC Biotechnol 10: 38.

96. Vanamala SK, Gopinath S, Gondi CS, Rao JS (2009) Effect of human umbilical cord blood cells on Ang-Il-induced hypertrophy in mice. Biochem Biophys Res Commun 386: 386-391.

97. van de Ven C, Collins D, Bradley MB, Morris E, Cairo MS (2007) The potential of umbilical cord blood multipotent stem cells for nonhematopoietic tissue and cell regeneration. Exp Hematol 35: 1753-1765.

98. Moelker AD, Baks T, Wever KM, Spitskovsky D, Wielopolski PA, et al. (2007) Intracoronary delivery of umbilical cord blood derived unrestricted somatic stem cells is not suitable to improve LV function after myocardial infarction in swine. $\mathrm{J}$ Mol Cell Cardiol 42: 735-745.

99. Murry CE, Soonpaa MH, Reinecke H, Nakajima H, Nakajima HO, et al. (2004) Haematopoietic stem cells do not transdifferentiate into cardiac myocytes in myocardial infarcts. Nature 428: 664-668.

100. Martin-Rendon E, Sweeney D, Lu F, Girdlestone J, Navarrete C, et al. (2008) 5-Azacytidine-treated human mesenchymal stem/progenitor cells derived from umbilical cord, cord blood and bone marrow do not generate cardiomyocytes in vitro at high frequencies. 95: 137-148.

101.Latifpour M, Nematollahi-Mahani SN, Deilamy M, Azimzadeh BS, EftekharVaghefi $\mathrm{SH}$, et al. (2011) Improvement in cardiac function following transplantation of human umbilical cord matrix-derived mesenchymal cells. Cardiology 120: 9-18.

102. Yan B, Abdelli LS, Singla DK (2011) Transplanted induced pluripotent stem cells improve cardiac function and induce neovascularization in the infarcted hearts of $\mathrm{db} / \mathrm{db}$ mice. Mol Pharm 8: 1602-1610.

103. Lakkisto P, Kyto V, Forsten H, Siren JM, Segersvard H, et al. (2010) Heme oxygenase-1 and carbon monoxide promote neovascularization after myocardial infarction by modulating the expression of HIF-1alpha, SDF1alpha and VEGF-B. Eur J Pharmacol 635: 156-164.

104. Hu CH, Li ZM, DU ZM, Zhang AX, Yang DY, et al. (2009) Human umbilical cord-derived endothelial progenitor cells promote growth cytokines-mediated neorevascularization in rat myocardial infarction. Chin Med J (Engl) 122: 548555.

105. Burchfield JS, Dimmeler S (2008) Role of paracrine factors in stem and progenitor cell mediated cardiac repair and tissue fibrosis. Fibrogenesis Tissue Repair 1: 4.

106. Pons J, Huang Y, Takagawa J, Arakawa-Hoyt J, Ye J, et al. (2009) Combining angiogenic gene and stem cell therapies for myocardial infarction. J Gene Med 11: 743-753

107.Tang YL, Zhao Q, Qin X, Shen L, Cheng L, et al. (2005) Paracrine action enhances the effects of autologous mesenchymal stem cell transplantation on vascular regeneration in rat model of myocardial infarction. Ann Thorac Surg 80: 229-237.

108. Chi NH, Yang MC, Chung TW, Chen JY, Chou NK, et al. (2012) Cardiac repair achieved by bone marrow mesenchymal stem cells/silk fibroin/hyaluronic acid patches in a rat of myocardial infarction model. Biomaterials 33: 5541-5551.

109. Henning RJ, Burgos JD, Vasko M, Alvarado F, Sanberg CD, et al. (2007) Human cord blood cells and myocardial infarction: effect of dose and route of administration on infarct size. Cell Transplant 16: 907-917.

110. Pinho-Ribeiro V, Maia AC, Werneck-de-Castro JP, Oliveira PF, Goldenberg RC, et al. (2010) Human umbilical cord blood cells in infarcted rats. Braz J Med Biol Res 43: 290-296.

111. Iwasaki H, Kawamoto A, Willwerth C, Horii M, Oyamada A, et al. (2009) Therapeutic potential of unrestricted somatic stem cells isolated from placenta cord blood for cardiac repair post myocardial infarction. Arterioscler Thromb Vasc Biol 29: 1830-1835.

112. van Dijk A, Naaijkens BA, Jurgens WJ, Nalliah K, Sairras S, et al. (2011) Reduction of infarct size by intravenous injection of uncultured adipose derived stromal cells in a rat model is dependent on the time point of application. Stem Cell Res 7: 219-229.

113. Xing YL, Shen LH, Li HW, Zhang YC, Zhao L, et al. (2009) Optimal time for human umbilical cord blood cell transplantation in rats with myocardial infarction. Chin Med J (Engl) 122: 2833-2839.

114. Schlechta B, Wiedemann D, Kittinger C, Jandrositz A, Bonaros NE, et al (2010) Ex-vivo expanded umbilical cord blood stem cells retain capacity fo myocardial regeneration. Circ J 74: 188-194.

115. Senegaglia AC, Barboza LA, Dallagiovanna B, Aita CA, Hansen P, et al (2010) Are purified or expanded cord blood-derived CD133+ cells better at improving cardiac function? Exp Biol Med (Maywood) 235: 119-129.

116. Qian H, Yang Y, Huang J, Dou K, Yang G (2006) Cellular cardiomyoplasty by catheter-based infusion of stem cells in clinical settings. Transpl Immunol 16: $135-147$.

117. Manginas A, Goussetis E, Koutelou M, Karatasakis G, Peristeri I, et al. (2007) Pilot study to evaluate the safety and feasibility of intracoronary CD133(+) and CD133(-) CD34(+) cell therapy in patients with nonviable anterior myocardial infarction. Catheter Cardiovasc Interv 69: 773-781.

118. Bartunek J, Vanderheyden M, Vandekerckhove B, Mansour S, De Bruyne B et al. (2005) Intracoronary injection of CD133-positive enriched bone marrow progenitor cells promotes cardiac recovery after recent myocardial infarction: feasibility and safety. Circulation 112: I178-183.

119. Wu KH, Han ZC, Mo XM, Zhou B (2012) Cell delivery in cardiac regenerative therapy. Ageing Res Rev 11: 32-40.

120. Mangi AA, Noiseux N, Kong D, He H, Rezvani M, et al. (2003) Mesenchymal stem cells modified with Akt prevent remodeling and restore performance of infarcted hearts. Nat Med 9: 1195-1201.

121. Matsumoto R, Omura T, Yoshiyama M, Hayashi T, Inamoto S, et al. (2005) Vascular endothelial growth factor-expressing mesenchymal stem cell transplantation for the treatment of acute myocardial infarction. Arterioscler Thromb Vasc Biol 25: 1168-1173.

122. Horita Y, Honmou O, Harada K, Houkin K, Hamada H, et al. (2006) Intravenous administration of glial cell line-derived neurotrophic factor gene-modified human mesenchymal stem cells protects against injury in a cerebral ischemia model in the adult rat. J Neurosci Res 84: 1495-1504.

123. Lee EJ, Park SJ, Kang SK, Kim GH, Kang HJ, et al. (2012) Spherical Bulle Formation via E-cadherin Promotes Therapeutic Potency of Mesenchymal Stem Cells Derived From Human Umbilical Cord Blood for Myocardial Infarction. Mol Ther 20: 1424-1433.

124. Lee WY, Wei HJ, Wang JJ, Lin KJ, Lin WW, et al. (2012) Vascularization and restoration of heart function in rat myocardial infarction using transplantation of human cbMSC/HUVEC core-shell bodies. Biomaterials 33: 2127-2136.
This article was originally published in a special issue, Cell Therapy for Neurological Disorders handled by Editor(s). Dr. Pranela Rameshwar, UMDNJ-New Jersey Medical School, USA 